Article

\title{
Establishing Boundary Conditions Considering Influence Factors of the Room Equipped with a Ceiling Radiant Cooling Panel
}

\author{
Sang-Hoon Park ${ }^{1}{ }^{\mathbb{D}}$, Dong-Woo Kim ${ }^{2}{ }^{\mathbb{D}}$, Goo-Sang Joe ${ }^{3}$, Seong-Ryong Ryu ${ }^{4, *}$, \\ Myoung-Souk Yeo ${ }^{2}$ and Kwang-Woo Kim ${ }^{2}$ \\ 1 Division of Architecture, College of Engineering, Sun Moon University, Chungnam 31460, Korea; \\ sanghoon@sunmoon.ac.kr \\ 2 Department of Architecture and Architectural Engineering, College of Engineering, \\ Seoul National University, Seoul 08826, Korea; aeekdw@snu.ac.kr (D.-W.K.); msyeo@snu.ac.kr (M.-S.Y.); \\ snukkw@snu.ac.kr (K.-W.K.) \\ 3 Goo-Sang Joe, Energy Platform Business Unit, Korea Telecom, Seoul 03155, Korea; goosang.joe@kt.com \\ 4 School of Architecture, Kumoh National Institute of Technology, Gyeongbuk 39177, Korea \\ * Correspondence: archiryu@kumoh.ac.kr; Tel.: +82-54-478-7592
}

Received: 31 January 2020; Accepted: 26 March 2020; Published: 3 April 2020

check for updates

\begin{abstract}
The objective of this study is to establish boundary conditions to evaluate the cooling capacity of the Cooling Radiant Ceiling Panel (CRCP) considering the environment of a room equipped with the CRCP. The current study investigated the boundary conditions and derivation techniques from previous studies. Based on the results of the analysis, a heat transfer model was derived for a room fitted with CRCP. In addition, the heat transfer model was used to derive the factors affecting the cooling capacity of the CRCP and each factor was simulated and verified through this model. The effects of these factors on the capacity of the CRCP was established by using various boundary conditions. To verify the validity of the simulation model, the experimental results were compared with the cooling capacity for a specific case. As a result, it was established that even for the same panel, there was a variance in the cooling capacity of the CRCP based on the boundary conditions and that the influence of the surface exposed to the outdoors had more implications. Consequently, this study presents the influence factors to be considered when designing CRCP.
\end{abstract}

Keywords: cooling capacity; cooling radiant ceiling panel; boundary condition; heat transfer model

\section{Introduction}

Cooling Radiant Ceiling Panel (CRCP) is a system that uses cold water to reduce the thermal load and is installed on the ceiling of buildings [1]. CRCP can be applied not only to homes but also to spaces with large ceiling areas such as classrooms [2]. In order to eliminate the thermal load efficiently, it is crucial to estimate the cooling capacity of the CRCP [3]. For accurate evaluation, it is necessary to evaluate the cooling capacity on the boundary condition when the panels are installed in the actual building (Figure 1). 


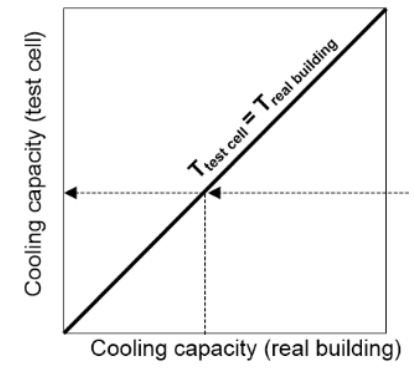

(a)

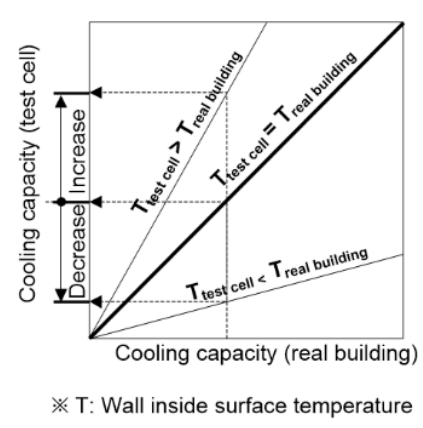

(b)

Figure 1. Evaluation of the cooling capacity of the Cooling Radiant Ceiling Panel (CRCP): (a) cooling capacity of the CRCP; (b) over or underestimated cooling capacity.

In the actual building space, the CRCP uses radiation and convection heat transfer to cool the air. Therefore, it is necessary to implement the environment in which the panel can radiate and transfer convective heat as much as in the actual building space.

To evaluate the amount of heat transfer in the actual building space, the air and surface temperature should be set at the same temperature as the actual building during the evaluation (Figure 2). However, the techniques used to evaluate the cooling capacity of the panel estimates the amount of heat that a panel removes from a thermal load generated by a cooling load simulator fitted in the test room [4]. In this case, the surface temperature and the air temperature are kept constant, in order to remove only the thermal load generated by a cooling load simulator. The same surface temperature is not applied since the variations due to the influencing factors in the surrounding environment are unknown. The aim of this study is to clarify the relationship between the influencing factors and the surface temperature, and to establish the same boundary conditions in order to evaluate the cooling capacity of the CRCP. It is expected that the actual amount of cooling capacity of the CRCP could be measured in the boundary conditions when the CRCP is installed in the actual building space for the cooling system design.

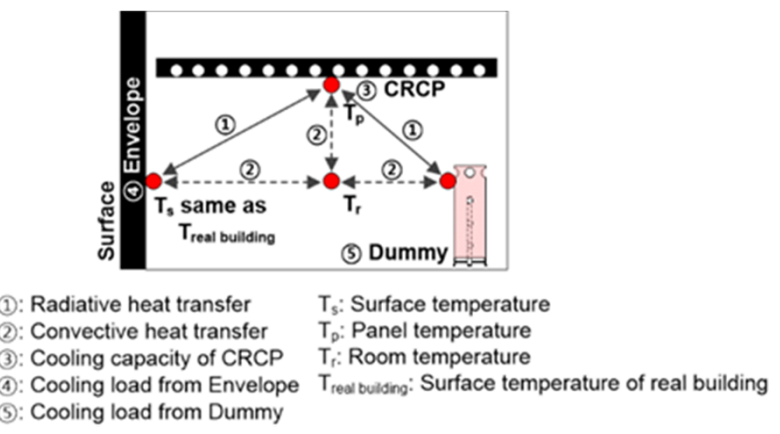

Figure 2. Cooling capacity evaluation regarding boundary condition.

\section{Preliminary Study}

\subsection{Types of CRCP}

The cooling radiant ceiling panel consists of pipes that circulate cold water to the panel in order to remove the thermal load generated in the room and maintain the room in a thermally comfortable state. In order to derive the boundary condition for evaluating the cooling capacity of CRCP, it is necessary to describe the concept of the CRCP and the cooling capacity. In this study, the type of ceiling panel is defined to be evaluated based on the distinction by the American Society of Heating, Refrigerating and Air-Conditioning Engineers (ASHRAE) and Representatives of European Heating 
and Ventilation Associations (REHVA) [4-6]. In both ASHRAE and REHVA, CRCPs are defined as devices that radiate heat using piping suspended at regular spaces from the ceiling (Table 1). The CRCP consists of insulation, piping, and a heat sink.

Table 1. Type of Cooling Radiant Ceiling Panel.

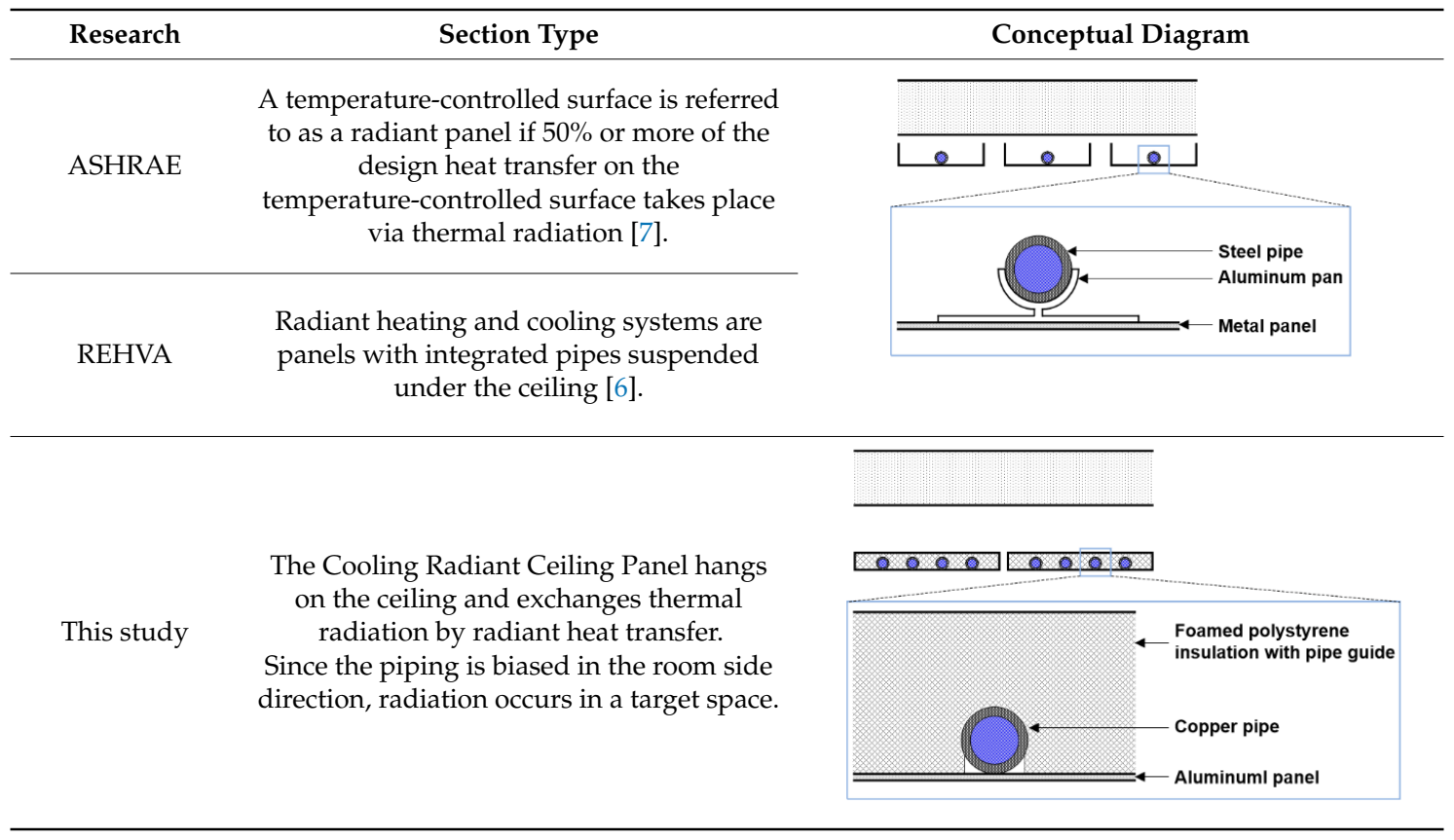

\subsection{Current Evaluation Method of the Cooling Capacity of the CRCP}

In the Lawrence Berkeley National Laboratory (LBNL) study, the amount of heat transferred from the CRCP surface to the room wall surface and the room air is referred to as the cooling power of the CRCP. In this case, the amount of cooling of the CRCP is the amount of convection and radiation heat exchange due to the difference in the surface temperature and the air temperature in the installation area of the CRCP.

Table 2 presents the formula used in calculating the cooling capacity of the CRCP based on the LBNL study and ASHRAE [7,8]. In both studies, the cooling capacity is divided into a convection component and a radiation component, which is a function of the temperature of each surface. The cooling capacity of the CRCP could be obtained by combining the convection and radiation components.

Table 2. Concept of cooling capacity of CRCP in the Lawrence Berkeley National Laboratory (LBNL) study and American Society of Heating, Refrigerating and Air-Conditioning Engineers (ASHRAE).

\begin{tabular}{|c|c|c|}
\hline Contents & LBNL Study [8] & ASHRAE [7] \\
\hline Concept & \multicolumn{2}{|c|}{$\begin{array}{l}\text { Heat exchange among temperature-controlled (active) surfaces, room surfaces, and room air } \\
\text { Sum of convective and radiative heat transfer }\end{array}$} \\
\hline Equation & $\begin{array}{l}q_{c}=h_{c}\left(t_{\text {air }}-t_{\text {surface }}\right) \\
q_{r}=\sigma F_{a} F_{e}\left[\left(\frac{T_{r}}{100}\right)^{4}-\left(\frac{T_{p}}{100}\right)^{4}\right]\end{array}$ & $\begin{array}{l}q_{c}=2.42 \frac{\left|t_{p}-t_{a}\right|^{0.31}\left(t_{p}-t_{a}\right)}{D_{e}^{0.08}} \\
q_{r}=J_{p}-\sum_{j=1}^{n} F_{p j} J_{j}\end{array}$ \\
\hline Symbol & $\begin{array}{c}q: \text { sum of convective and radiant heat transfer } \\
q_{c}: \text { heat transfer by convection } \\
q_{r}: \text { heat transfer by radiation } \\
h_{c}: \text { convective coefficient } \\
t_{\text {air }}: \text { room air temperature } \\
t_{\text {surface }}: \text { surface temperature } \\
\sigma: \text { Stefan-Boltzmann constant } \\
F_{a}: \text { configuration factor } \\
F_{e}: \text { emissivity factor } \\
T_{r}: \text { mean radiant temperature (MRT) of unconditioned surface } \\
T_{p}: \text { mean radiant temperature (MRT) of cooled surface }\end{array}$ & $\begin{array}{c}t_{p}: \text { effective temperature of temperature-controlled surface } \\
t_{a}: \text { indoor space dry-bulb air temperature } \\
D_{e}: \text { equivalent diameter of panel } \\
J_{p}: \text { total radiosity leaving or reaching panel surface } \\
F_{p j}: \text { radiation angle factor between panel surface and } \\
\text { another surface in room } \\
J_{j}: \text { radiosity from or to another surface in room } \\
n: \text { number of surfaces in room other than panels }\end{array}$ \\
\hline
\end{tabular}


Table 3 presents the previous studies focused on evaluating the cooling capacity of CRCP. According to Kochendorfer's study, the problem is that the amount of cooling in the same panel may vary due to irregular surroundings, while the amount of cooling capacity may vary depending on the non-uniform environment [9]. Notably, previous studies have highlighted that the boundary condition could be changed by the envelope. The effect of the envelope is that the indoor boundary condition of the surface exposed to the outside air may be changed based on the thermal load generated by the envelope space where the CRCP is installed. This means that the amount of cooling of the CRCP can be changed [10]. In order to solve this problem, it is necessary to establish the non-uniform boundary condition at the environment of the actual building.

Table 3. Previous studies on irregular surrounding conditions.

\begin{tabular}{|c|c|}
\hline Author or Organization & Issues \\
\hline C. Kochendorfer [9] & $\begin{array}{l}\text { Evaluates the cooling capacity in an environment where there is no heat } \\
\text { exchange with the outside } \\
\text { The amount of cooling capacity may vary, based on the surface temperature } \\
\text { of the wall }\end{array}$ \\
\hline $\begin{array}{l}\text { N. Fonseca [3] } \\
\text { N. Fonseca et al. [10] }\end{array}$ & Estimates the cooling capacity of the panel based on the external load \\
\hline M. De Carli et al. [11] & $\begin{array}{l}\text { The cooling capacity of the ceiling radiation panel is estimated using } \\
\text { unsteady state analysis in consideration of the external load }\end{array}$ \\
\hline Z. Tian et al. [12] & $\begin{array}{l}\text { The cooling capacity of the panel is calculated based on the window to the } \\
\text { wall ratio considering the influence of the window-installed envelope }\end{array}$ \\
\hline EN14240 [13] & $\begin{array}{l}\text { Since the material enclosing the CRCP could affect the cooling capacity of } \\
\text { the panel, the adiabatic boundary condition is maintained to prevent the } \\
\text { influence of the envelope }\end{array}$ \\
\hline NT VVS 078 [14] & Same as EN14240 \\
\hline
\end{tabular}

\subsection{Concept for Establishing Boundary Condition}

The amount of cooling capacity may vary depending on the analysis of the plenum and the room. The concept for establishing the boundary condition in this study can be summarized through the analysis of the plenum and the analysis of room. Thus far, it is still unclear how the surface temperature caused by the boundary conditions affects the convection and radiative heat transfer in the room fitted with CRCP. In addition, the effect of the boundary condition influencing factors on the cooling capacity of CRCP has not been clarified. Thus, it is necessary to study the relationship between the cooling capacity and the influencing factors on the wall, ceiling, and floor surface temperature in the analysis of the plenum and room.

\section{Environment of Room Equipped with CRCP}

\subsection{Heat Transfer Model of Room Equipped with CRCP}

In order to establish the boundary condition for evaluating the cooling capacity of the CRCP, the influencing factors affecting the boundary conditions must be analyzed. In this study, the heat transfer process in the plenum and the room is analyzed by establishing the heat transfer model of the test room where the CRCP is installed based on the heat transfer model of ASHRAE (schematic of heat balance processes in zone) to figure out the influencing factors [15]. The heat transfer model in the space with the CRCP based on the ASHRAE model, consists of three parts: a plenum, a ceiling with a panel, and a room. In the actual building, the heat transfer occurs as shown in Figure 3. In the test room, convective heat transfer occurs between the room air and the bottom face of the ceiling, while radiative heat transfer occurs between the zone inside face and the bottom face of the ceiling. Finally, Figure 4 shows the simplified heat transfer model of the test room equipped with the CRCP. 


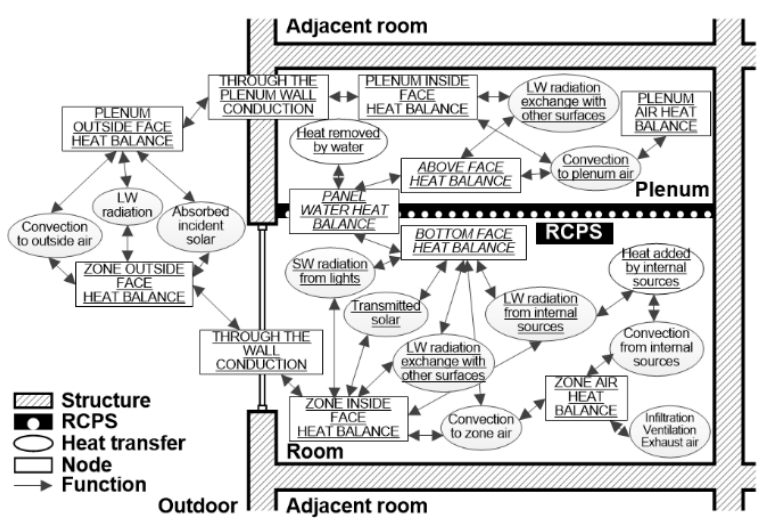

Figure 3. Heat transfer in a space equipped with CRCP.

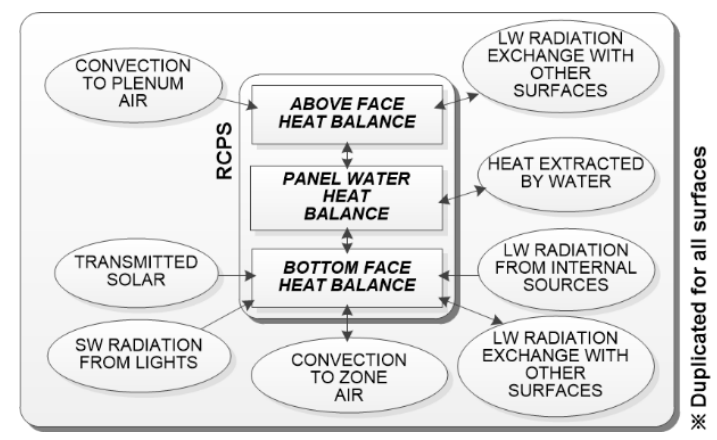

Figure 4. Simplified heat transfer model of test room equipped with CRCP.

\subsection{Influencing Factors of Cooling Capacity}

From the heat transfer model of a test room with $\mathrm{CRCP}$, the influencing factors in the space are identified. Depending on the characteristics of these factors in the heat transfer model, the boundary condition influencing factors could be categorized into three groups: Group 1 Site and Building, Group 2 Wall Composition, and Group 3 Internal Heat Gain. By analyzing the factors belonging to each group and removing the redundant factors and simplifying them, the factors in each group can be set as in Table 4:

Table 4. Group and influencing factors in each group.

\begin{tabular}{cc}
\hline Groups & Influencing Factors \\
\hline Group 1: Site and building & $\begin{array}{c}\text { Sol-air temperature } \\
\text { Group 2: Wall composition }\end{array}$ \\
& Number of surfaces exposed to the outdoors \\
\hline Group 3: Internal heat gain & $\begin{array}{c}\text { Heat transmission coefficient } \\
\text { Surface heat absorption rate }\end{array}$ \\
\hline
\end{tabular}

Group 1 includes the sol-air temperature and the number of surfaces exposed to outdoor air. Considering the situation of the test room in which the sun cannot be accessed, the outside temperature was a substantial source of the sol-air temperature and the temperature increased with the increase in the amount of heat introduced into the room through the walls. The number of faces exposed to the outdoors is a factor that can influence the temperature difference between the outside environment and the test room. Group 2 consists of the material and composition of the wall, the heat transmission coefficient, and the surface heat absorption rate [15]. The material and composition of the wall can be 
determined by the structure of the wall, the build of the material, and the presence of either outdoor or indoor insulation. The surface heat absorption rate is a coefficient associated with radiative heat transfer, and can be used to determine how the interior surface finishing of the wall affects the boundary conditions. Group 3 consists of a boundary condition influencing factor associated with the amount and the components of internal heat gain [15-18].

\subsection{Values and Ranges of Influencing Factors}

The values and ranges of these factors affect every heat transfer process and are derived as shown in Table 5 based on previous research and international standard analysis [3,4,7]. The sol-air temperature of Group 1 is the ambient temperature of the building located at 36 degrees north latitude. The wall heat transmission coefficient of $2.02 \mathrm{~W} / \mathrm{m}^{2} \mathrm{~K}$ is the minimum design requirement for the wall heat transfer rate and $0.15 \mathrm{~W} / \mathrm{m}^{2} \mathrm{~K}$ is the insulation standard for passive houses. Table 5 is the reference for setting the values, ranges, and values of each factor.

Table 5. Value of influencing factors.

\begin{tabular}{|c|c|c|c|}
\hline Groups & Factors & Unit & Value and Range \\
\hline \multirow{8}{*}{ Group 1} & \multirow{4}{*}{ Sol-air temperature } & \multirow{4}{*}{$\left({ }^{\circ} \mathrm{C}\right)$} & 30 \\
\hline & & & 40 \\
\hline & & & 50 \\
\hline & & & 60 \\
\hline & \multirow{4}{*}{$\begin{array}{l}\text { Number of surfaces exposed to } \\
\text { the outdoors }\end{array}$} & \multirow{4}{*}{$(-)$} & 1 \\
\hline & & & 2 \\
\hline & & & 3 \\
\hline & & & 4 \\
\hline \multirow{12}{*}{ Group 2} & \multirow{4}{*}{ Material and composition of wall } & \multirow{4}{*}{$(-)$} & Lightweight \\
\hline & & & Heavyweight \\
\hline & & & Outside-insulation \\
\hline & & & Inside-insulation \\
\hline & \multirow{5}{*}{ Heat transmission coefficient } & \multirow{5}{*}{$\left(\mathrm{W} / \mathrm{m}^{2} \mathrm{~K}\right)$} & 2.02 \\
\hline & & & 0.66 \\
\hline & & & 0.39 \\
\hline & & & 0.22 \\
\hline & & & 0.15 \\
\hline & \multirow{3}{*}{ Surface heat absorption rate } & \multirow{3}{*}{$(-)$} & 0.1 \\
\hline & & & 0.6 \\
\hline & & & 0.9 \\
\hline \multirow{6}{*}{ Group 3} & \multirow{3}{*}{$\begin{array}{l}\text { Component of internal heat gain: } \\
\text { Radiant Fraction }\end{array}$} & \multirow{3}{*}{$(-)$} & 1.0 \\
\hline & & & 0.6 \\
\hline & & & 0.0 \\
\hline & \multirow{3}{*}{ Amount of internal heat gain } & \multirow{3}{*}{$(\mathrm{W})$} & 59 \\
\hline & & & 235 \\
\hline & & & 411 \\
\hline
\end{tabular}

The Group 2 wall material is assumed to vary, whereas the rate of heat transfer is the same (e.g., concrete wall, insulation wall). In addition, the composition of the wall varies from the inside to the outside based on the construction method. By setting the heat transmission coefficient of all the walls to $2.02 \mathrm{~W} / \mathrm{m}^{2} \mathrm{~K}$ as in Table 6, only the influence of the boundary condition due to the wall structure, which is dependent on the material of the wall and the composition of the insulation, can be evaluated. 
Table 6. Material and composition of wall.

\begin{tabular}{|c|c|c|c|c|c|c|}
\hline \multirow[b]{2}{*}{ Factors } & \multirow[b]{2}{*}{$\begin{array}{l}\text { Composition } \\
\text { (Outside to } \\
\text { Inside) }\end{array}$} & \multicolumn{5}{|c|}{ Specifications } \\
\hline & & $\begin{array}{l}\text { Thickness } \\
\text { (m) }\end{array}$ & $\begin{array}{c}\text { Specific Heat } \\
(\mathrm{J} / \mathrm{kgK})\end{array}$ & $\begin{array}{c}\text { Conductivity } \\
\text { (W/mK) }\end{array}$ & $\begin{array}{c}\text { Surface Heat } \\
\text { Absorption Rate } \\
(-)\end{array}$ & $\begin{array}{l}\text { Heat Transmission } \\
\text { Coefficient } \\
\left(\mathrm{W} / \mathrm{m}^{2} \mathrm{~K}\right)\end{array}$ \\
\hline Inside insulated wall & Insulation 13 & 0.013 & 265 & 0.049 & 0.1 & 2.02 \\
\hline Outside insulated wall & Insulation 13 & 0.013 & 265 & 0.049 & 0.1 & 2.02 \\
\hline Insulation wall & Insulation 17 & 0.017 & 265 & 0.049 & 0.1 & 2.02 \\
\hline
\end{tabular}

If the material and composition of the wall are the same, the boundary condition of the wall can vary as a result of the change in the thermal conductivity based on the wall thickness. Table 7 shows that the thermal conductivity of the wall utilized for this study varies from 2.02 to $0.15 \mathrm{~W} / \mathrm{m}^{2} \mathrm{~K}$ by intervals of 0.07 .

Table 7. Heat transmission coefficient of wall.

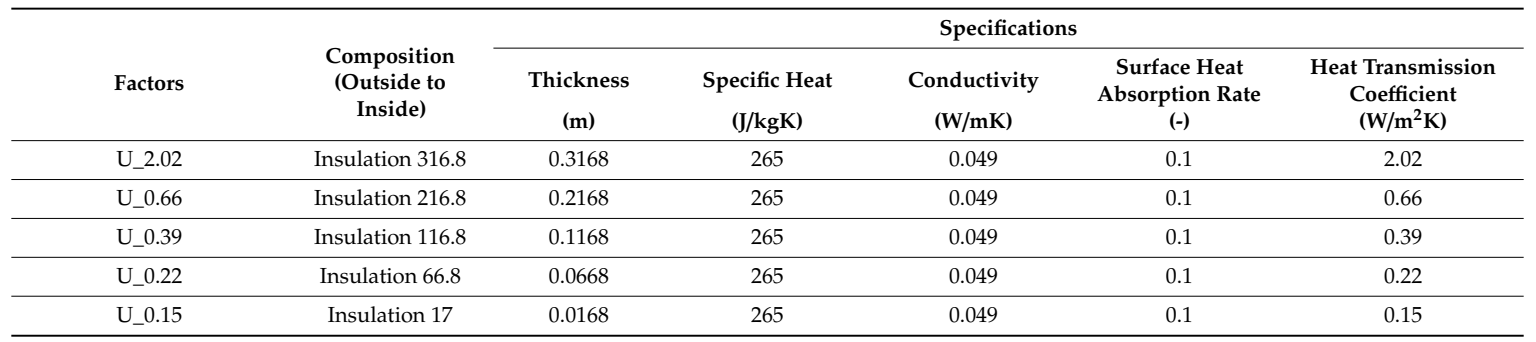

\section{Evaluation of Boundary Condition of the CRCP Equipped Room}

\subsection{Concept of the Boundary Condition Derivation Model}

In order to derive the boundary condition based on the influence factor changes, the CRCP installed space was modeled via simulation. Table 8 shows that the boundary condition derivation model is implemented in six steps. In step 1, the simulated input variables were derived from the influencing factor and the range of values or values of each factor. In step 2, the room fitted with CRCP and the adjacent room were modeled as in Figure 5, such that it is possible to set the desired influence factors in the space to be analyzed. In step 3, a CRCP and an air conditioning system were modeled in the main room and the adjacent room to derive the thermal load. Specifically, the air conditioning system was operated while the CRCP remained off, and the thermal load removed by the air conditioning system was estimated. The cooling capacity of the CRCP necessary to maintain the set temperature can be estimated. In steps 4 and 5 , the process of finding the correct supply water temperature to satisfy the set room temperature, was reiterated by simulation using a fixed flow rate. In step 6, the boundary condition of the test room where the CRCP is installed was finally derived when the CRCP was in operation.

Table 8. Modeling process to evaluate the boundary condition.

\begin{tabular}{cr}
\hline Step & Modeling Process \\
\hline 1 & Set simulation input variables \\
\hline 2 & Configure the main room and the adjacent room to set the desired influencing factors on the space \\
\hline 3 & Derive the thermal load to be eliminated to maintain the space to the set-point room temperature \\
\hline 5 & Determine the supply water temperature and water flow rate to eliminate the thermal load \\
\hline 6 & Calculate and reset the supply water temperature to maintain the set point room temperature \\
\hline
\end{tabular}




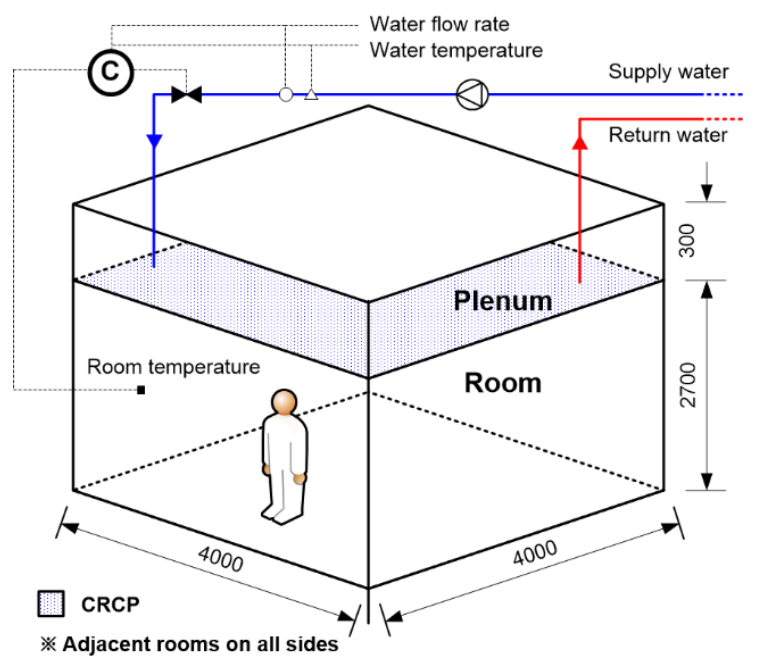

Figure 5. Modeling of room and CRCP.

\subsection{Simulation Model for Evaluating Boundary Condition}

The simulation model for evaluating boundary conditions was implemented with the aim of obtaining the boundary condition when the CRCP is in operation under the various influencing factors. EnergyPlus V8-1-0 and LabVIEW were used for simulation. EnergyPlus is suited for radiation and convection heat transfer on the surface, since a heat balance-based solution is possible [19]. The boundary condition based on the varying factors can be used as the output data. In addition, the iterative calculation processes to find the supply water mentioned in step 5 of Section 4.1 were performed by linking LabVIEW and EnergyPlus. The size of the space is $4.0 \mathrm{~m}$ (width) $\times 4.0 \mathrm{~m}$ (depth) $\times 3.0 \mathrm{~m}$ (height), as shown in Figure 5. The CRCP and air conditioning system are installed in each zone. In this study, the CRCP was modeled using a self-developed product. Figure 6 shows the system flow chart of the CRCP installed in the test room.

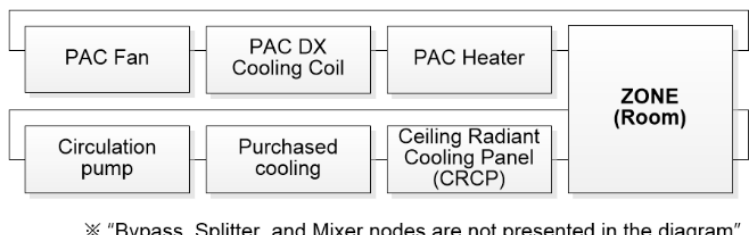

※ "Bypass, Splitter, and Mixer nodes are not presented in the diagram" ※ The same systems are applied to the other rooms

Figure 6. Flow chart representing the system configuration of the simulation model.

\subsection{Simulation Results}

\subsubsection{Boundary Conditions on Wall Composition}

- Material and composition of wall

Table 9 shows the changes in surface temperature that were obtained in the analysis to determine the effect of the wall thickness and layer composition on the boundary conditions. 
Table 9. Cases for material and composition of wall.

\begin{tabular}{|c|c|c|c|c|c|c|c|c|}
\hline \multirow[b]{2}{*}{ Cases } & \multicolumn{2}{|c|}{ Group 1} & \multicolumn{4}{|c|}{ Group 2} & \multicolumn{2}{|c|}{ Group 3} \\
\hline & $\begin{array}{c}\text { Sol-Air Temp. } \\
\left({ }^{\circ} \mathrm{C}\right)\end{array}$ & $\begin{array}{c}\text { Number of Faces } \\
\text { Exposed to } \\
\text { Outdoor Air } \\
(-)\end{array}$ & $\begin{array}{c}\text { Material and } \\
\text { Composition } \\
(-)\end{array}$ & $\begin{array}{c}\text { Thickness } \\
\text { (m) }\end{array}$ & $\begin{array}{c}\text { Heat } \\
\text { Transmission } \\
\text { Coefficient } \\
\left(\mathrm{W} / \mathrm{m}^{2} \mathrm{~K}\right)\end{array}$ & $\begin{array}{c}\text { Surface Heat } \\
\text { Absorption } \\
\text { Rate } \\
(-)\end{array}$ & $\begin{array}{c}\text { Radiant } \\
\text { Fraction } \\
\qquad(-)\end{array}$ & $\begin{array}{c}\text { Heat } \\
\text { Amount } \\
\text { (W) }\end{array}$ \\
\hline \multirow{4}{*}{ In_Ins } & 60 & \multirow{4}{*}{1} & Concrete 100 & 0.1 & \multirow{4}{*}{2.02} & \multirow{4}{*}{0.1} & \multirow{4}{*}{0.6} & \multirow{4}{*}{411} \\
\hline & 50 & & (Outside) & & & & & \\
\hline & 40 & & Insulation 13 & 0.013 & & & & \\
\hline & 30 & & (Inside) & 0.010 & & & & \\
\hline \multirow{4}{*}{ Out_Ins } & 60 & \multirow{4}{*}{1} & Insulation 13 & 0.013 & \multirow{4}{*}{2.02} & \multirow{4}{*}{0.1} & \multirow{4}{*}{0.6} & \multirow{4}{*}{411} \\
\hline & 50 & & & & & & & \\
\hline & 40 & & Concrete 100 & 0.1 & & & & \\
\hline & 30 & & (Inside) & & & & & \\
\hline \multirow{4}{*}{ Conc_Wall } & 60 & \multirow{4}{*}{1} & \multirow{4}{*}{ Concrete 450} & \multirow{4}{*}{0.45} & \multirow{4}{*}{2.02} & \multirow{4}{*}{0.1} & \multirow{4}{*}{0.6} & \multirow{4}{*}{411} \\
\hline & 50 & & & & & & & \\
\hline & 40 & & & & & & & \\
\hline & 30 & & & & & & & \\
\hline \multirow{4}{*}{ Ins_Wall } & 60 & \multirow{4}{*}{1} & \multirow{4}{*}{ Insulation 17} & \multirow{4}{*}{0.017} & \multirow{4}{*}{2.02} & \multirow{4}{*}{0.1} & \multirow{4}{*}{0.6} & \multirow{4}{*}{411} \\
\hline & 50 & & & & & & & \\
\hline & 40 & & & & & & & \\
\hline & 30 & & & & & & & \\
\hline
\end{tabular}

The walls with the same heat transmission coefficient transmit the same amount of heat regardless of the wall composition. Therefore, in the steady-state under the same sol-air temperature, the wall internal surface temperatures having the same heat transmission coefficients have the same surface temperature.

However, in the unsteady-state where the sol-air temperature changes in the daytime, the indoor surface temperature of the surface exposed to the outside air also changes due to the heat storage. Figure 7 shows that the surface temperature of the lightweight wall is similar to the profile of the sol-air temperature, unlike in heavy wall. Since the outside insulated wall is influenced more by the heat storage, the change in the surface temperature of the indoor surface is smaller than that of the inside insulated wall.

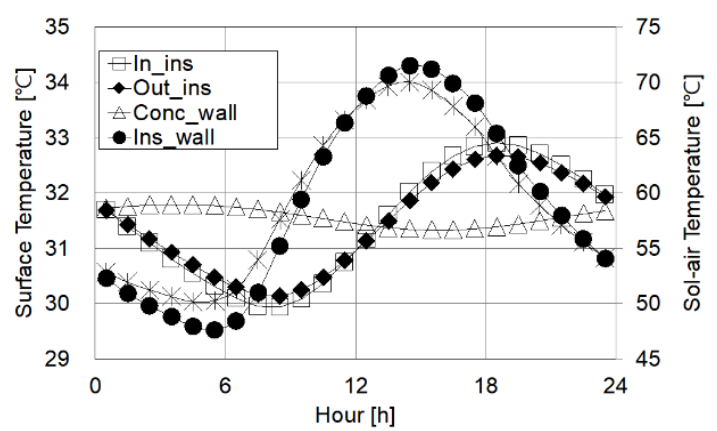

Figure 7. Surface temperature for the material and composition of wall (Unsteady-state).

- Heat transmission coefficient of wall

Table 10 shows the evaluation of the surface temperature of the wall with the same material properties composed of a single material. The change in the heat transmission coefficient was made by changing the thickness of the insulation from 0.017 to $0.3168 \mathrm{~mm}$. 
Table 10. Cases for heat transmission coefficient of wall.

\begin{tabular}{|c|c|c|c|c|c|c|c|c|}
\hline \multirow[b]{2}{*}{ Cases } & \multicolumn{2}{|c|}{ Group 1} & \multicolumn{4}{|c|}{ Group 2} & \multicolumn{2}{|c|}{ Group 3} \\
\hline & $\begin{array}{c}\text { Sol-Air Temp. } \\
\left({ }^{\circ} \mathrm{C}\right)\end{array}$ & $\begin{array}{c}\text { Number of Faces } \\
\text { Exposed to } \\
\text { Outdoor Air } \\
(-)\end{array}$ & $\begin{array}{c}\text { Material and } \\
\text { Composition } \\
(-)\end{array}$ & $\begin{array}{c}\text { Thickness } \\
\text { (m) }\end{array}$ & $\begin{array}{c}\text { Heat } \\
\text { Transmission } \\
\text { Coefficient } \\
\left(\mathrm{W} / \mathrm{m}^{2} \mathrm{~K}\right)\end{array}$ & $\begin{array}{c}\text { Surface Heat } \\
\text { Absorption } \\
\text { Rate } \\
(-)\end{array}$ & $\begin{array}{c}\text { Radiant } \\
\text { Fraction } \\
\text { (-) }\end{array}$ & $\begin{array}{c}\text { Heat } \\
\text { Amount } \\
\text { (W) }\end{array}$ \\
\hline \multirow{4}{*}{ U_2.02 } & 60 & \multirow{4}{*}{1} & \multirow{4}{*}{ Insulation 17} & \multirow{4}{*}{0.017} & \multirow{4}{*}{2.02} & \multirow{4}{*}{0.1} & \multirow{4}{*}{0.6} & \multirow{4}{*}{411} \\
\hline & 50 & & & & & & & \\
\hline & 40 & & & & & & & \\
\hline & 30 & & & & & & & \\
\hline \multirow{4}{*}{ U_0.66 } & 60 & \multirow{4}{*}{1} & \multirow{4}{*}{ Insulation 66.8} & \multirow{4}{*}{0.0668} & \multirow{4}{*}{0.66} & \multirow{4}{*}{0.1} & \multirow{4}{*}{0.6} & \multirow{4}{*}{411} \\
\hline & 50 & & & & & & & \\
\hline & 40 & & & & & & & \\
\hline & 30 & & & & & & & \\
\hline \multirow{4}{*}{ U_0.39 } & 60 & \multirow{4}{*}{1} & \multirow{4}{*}{$\begin{array}{c}\text { Insulation } \\
116.8\end{array}$} & \multirow{4}{*}{0.1168} & \multirow{4}{*}{0.39} & \multirow{4}{*}{0.1} & \multirow{4}{*}{0.6} & \multirow{4}{*}{411} \\
\hline & 50 & & & & & & & \\
\hline & 40 & & & & & & & \\
\hline & 30 & & & & & & & \\
\hline \multirow{4}{*}{ U_0.22 } & 60 & \multirow{4}{*}{1} & \multirow{4}{*}{$\begin{array}{c}\text { Insulation } \\
216.8\end{array}$} & \multirow{4}{*}{0.2168} & \multirow{4}{*}{0.22} & \multirow{4}{*}{0.1} & & \\
\hline & 50 & & & & & & 0.6 & 411 \\
\hline & 40 & & & & & & & \\
\hline & 30 & & & & & & & \\
\hline & 60 & & & & & & & \\
\hline U_0.15 & 50 & 1 & $\begin{array}{l}\text { Insulation } \\
3169\end{array}$ & 0.3168 & 0.15 & 0.1 & 0.6 & 411 \\
\hline & 40 & & & & & & & \\
\hline & 30 & & & & & & & \\
\hline
\end{tabular}

The surface temperature of the wall exposed to the outside air is decreased from 31.9 to $26.1{ }^{\circ} \mathrm{C}$ when the heat transmission coefficient of the wall changes from 2.02 to $0.15 \mathrm{~W} / \mathrm{m}^{2} \mathrm{~K}$ when the sol-air temperature is $60^{\circ} \mathrm{C}$ (Figure 8). This tendency is as a result of heat transmission coefficient being the determinant factor in the surface temperature of the wall in steady state conditions. When the sol-air temperature is $30^{\circ} \mathrm{C}$ the ambient temperature is not affected by the outside air, regardless of the heat transmission coefficient. Figure 9 shows that for the wall that is not exposed to the outside air, with exception of the front wall, the sol-air temperature has almost no influence.

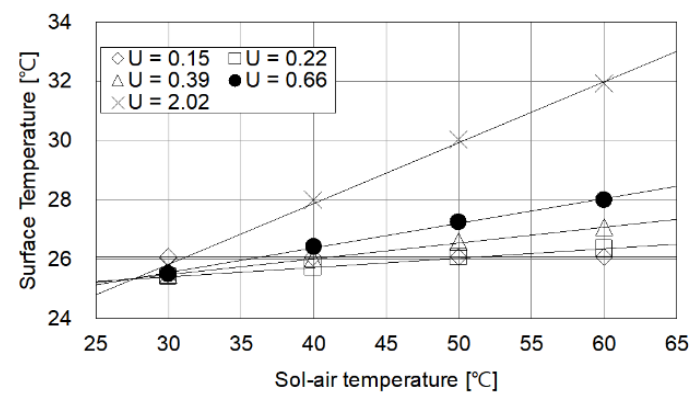

Figure 8. Sol-air temperature and surface temperature for the heat transmission coefficient of the wall.

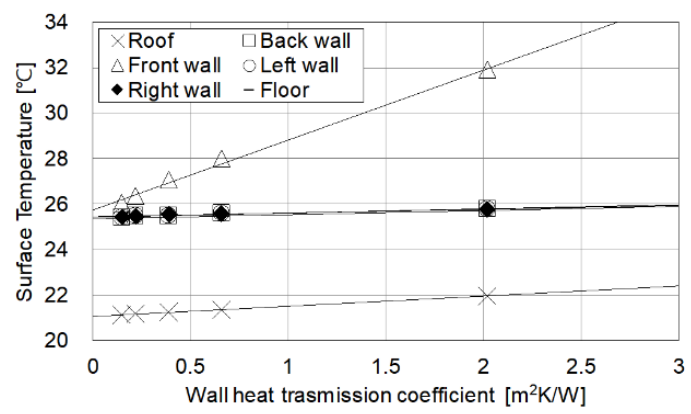

Figure 9. Heat transmission coefficient and surface temperature for each wall (Case U_2.02, sol-air temp $\left.=60^{\circ} \mathrm{C}\right)$. 
- Surface heat absorption rate of wall

Table 11 and Figure 10 show that the wall with high heat absorption rate on the surface exposed to the outside air has a large surface temperature change according to the change of the sol-air temperature.

Table 11. Cases for the surface heat absorption rate of the wall.

\begin{tabular}{|c|c|c|c|c|c|c|c|c|}
\hline \multirow[b]{2}{*}{ Cases } & \multicolumn{2}{|c|}{ Group 1} & \multicolumn{4}{|c|}{ Group 2} & \multicolumn{2}{|c|}{ Group 3} \\
\hline & $\begin{array}{c}\text { Sol-Air Temp. } \\
\left({ }^{\circ} \mathrm{C}\right)\end{array}$ & $\begin{array}{c}\text { Number of Faces } \\
\text { Exposed to } \\
\text { Outdoor Air } \\
(-)\end{array}$ & $\begin{array}{c}\text { Material and } \\
\text { Composition } \\
(-)\end{array}$ & $\begin{array}{c}\text { Thickness } \\
\text { (m) }\end{array}$ & $\begin{array}{c}\text { Heat } \\
\text { Transmission } \\
\text { Coefficient } \\
\left(\mathrm{W} / \mathrm{m}^{2} \mathrm{~K}\right)\end{array}$ & $\begin{array}{c}\text { Surface Heat } \\
\text { Absorption } \\
\text { Rate } \\
(-)\end{array}$ & $\begin{array}{c}\text { Radiant } \\
\text { Fraction } \\
\quad(-)\end{array}$ & $\begin{array}{c}\text { Heat } \\
\text { Amount } \\
\text { (W) }\end{array}$ \\
\hline \multirow{4}{*}{ Abs._0.1 } & 60 & & & & & & & \\
\hline & 50 & 1 & Insulation 17 & 0.017 & 2.02 & 0.1 & 0.6 & 411 \\
\hline & 40 & & & & & & & \\
\hline & 30 & & & & & & & \\
\hline \multirow{4}{*}{ Abs._0.6 } & 60 & & & & & & & \\
\hline & 50 & 1 & Insulation 17 & 0.017 & 2.02 & 0.6 & 0.6 & 411 \\
\hline & 40 & & & & & & & \\
\hline & 30 & & & & & & & \\
\hline \multirow{4}{*}{ Abs._0.9 } & 60 & & & & & & & \\
\hline & 50 & 1 & Insulation 17 & 0.017 & 2.02 & 0.9 & 0.6 & 411 \\
\hline & 40 & & & & & & & \\
\hline & 30 & & & & & & & \\
\hline
\end{tabular}

The higher the surface absorption rate of the wall, the more the boundary conditions are affected by the outside air. When the sol-air temperature is less than $30^{\circ} \mathrm{C}$ there is hardly any influence by the outside air, regardless of the surface heat absorption rate of the wall. However, as the ambient temperature increases, the influence of the surface heat absorption rate also increases.

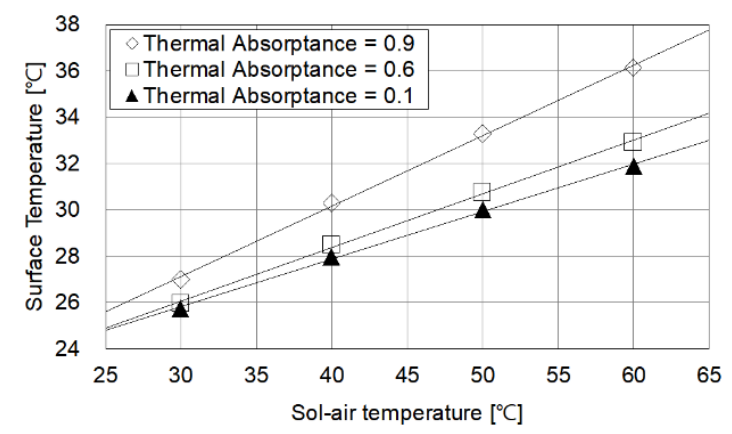

Figure 10. Sol-air temperature and surface temperature for the surface heat absorption rate of the wall.

\subsubsection{Boundary Conditions on Site and Building}

\section{- Sol-air temperature}

In the wall with the same thermal conductivity, the inner surface temperature of the exposed surface is higher, since the sol-air temperature is higher (Table 12). As the sol-air temperature rises from 30 to $60{ }^{\circ} \mathrm{C}$ in the wall with $2.02 \mathrm{~W} / \mathrm{m}^{2} \mathrm{~K}$, the indoor surface temperature of the exposed surface also rises from 25.7 to $31.9^{\circ} \mathrm{C}$ Conversely, when the heat transmission coefficient of the wall is as low as the level of the passive house, the sol-air temperature has little effect on the surface temperature (Figure 11). 
Table 12. Cases for sol-air temperature.

\begin{tabular}{|c|c|c|c|c|c|c|c|c|}
\hline \multirow[b]{2}{*}{ Cases } & \multicolumn{2}{|c|}{ Group 1} & \multicolumn{4}{|c|}{ Group 2} & \multicolumn{2}{|c|}{ Group 3} \\
\hline & $\begin{array}{c}\text { Sol-Air Temp. } \\
\left({ }^{\circ} \mathrm{C}\right)\end{array}$ & $\begin{array}{c}\text { Number of Faces } \\
\text { Exposed to } \\
\text { Outdoor Air } \\
(-)\end{array}$ & $\begin{array}{c}\text { Material and } \\
\text { Composition } \\
(-)\end{array}$ & $\begin{array}{c}\text { Thickness } \\
\text { (m) }\end{array}$ & $\begin{array}{c}\text { Heat } \\
\text { Transmission } \\
\text { Coefficient } \\
\left(\mathrm{W} / \mathrm{m}^{2} \mathrm{~K}\right)\end{array}$ & $\begin{array}{c}\text { Surface Heat } \\
\text { Absorption } \\
\text { Rate } \\
(-)\end{array}$ & $\begin{array}{l}\text { Radiant } \\
\text { Fraction } \\
\quad(-)\end{array}$ & $\begin{array}{c}\text { Heat } \\
\text { Amount } \\
\text { (W) }\end{array}$ \\
\hline \multirow{3}{*}{ Sol_60 } & \multirow{3}{*}{60} & \multirow{3}{*}{1} & \multirow{3}{*}{ Insulation 17} & \multirow{3}{*}{0.017} & \multirow{3}{*}{2.02} & \multirow{3}{*}{0.1} & \multirow{3}{*}{0.6} & 411 \\
\hline & & & & & & & & 235 \\
\hline & & & & & & & & 59 \\
\hline \multirow{3}{*}{ Sol_50 } & \multirow{3}{*}{50} & \multirow{3}{*}{1} & \multirow{3}{*}{ Insulation 66.8} & \multirow{3}{*}{0.0668} & \multirow{3}{*}{0.66} & \multirow{3}{*}{0.1} & \multirow{3}{*}{0.6} & 411 \\
\hline & & & & & & & & 235 \\
\hline & & & & & & & & 59 \\
\hline \multirow{3}{*}{ Sol_40 } & \multirow{3}{*}{40} & \multirow{3}{*}{1} & \multirow{3}{*}{$\begin{array}{c}\text { Insulation } \\
116.8\end{array}$} & \multirow{3}{*}{0.1168} & \multirow{3}{*}{0.39} & \multirow{3}{*}{0.1} & \multirow{3}{*}{0.6} & 411 \\
\hline & & & & & & & & 235 \\
\hline & & & & & & & & 59 \\
\hline \multirow{2}{*}{ Sol_30 } & \multirow{2}{*}{30} & \multirow{2}{*}{1} & \multirow{2}{*}{$\begin{array}{c}\text { Insulation } \\
216.8\end{array}$} & \multirow{2}{*}{0.2168} & \multirow{2}{*}{0.22} & \multirow[b]{2}{*}{0.1} & \multirow[b]{2}{*}{0.6} & 411 \\
\hline & & & & & & & & 235 \\
\hline
\end{tabular}

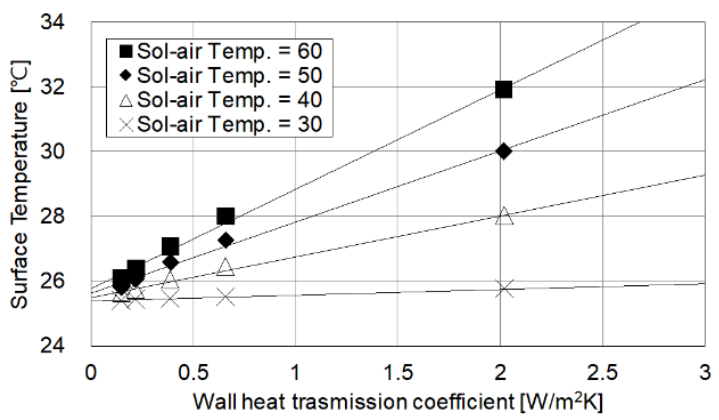

Figure 11. Wall heat transmission coefficient and surface temperature for sol-air temperature.

- Number of surfaces exposed to outdoor air

The larger the number of exposed surfaces to the outside environment under the same sol-air temperature, the greater the increase in surface temperature. However, the temperature changes of each surface are very small (approximately less than $1{ }^{\circ} \mathrm{C}$ ). The surface temperature increases linearly with the ambient temperature, regardless of the number of surfaces exposed to the outside environment.

\subsubsection{Boundary Conditions on Internal Heat Gain}

In order to understand the effect of internal heat gain on the boundary condition, the evaluation cases are presented as in Tables 13-15, and the surface temperature and the temperature change trend in each case were derived.

- Amount of internal heat gain

As the internal heat gain increases, there is a corresponding surface temperature change (Figure 12). In particular, when the internal heat gain is $411 \mathrm{~W}$, the surface temperature change is $1.8^{\circ} \mathrm{C}$ as the radiation component of the internal heat gain changes from 0 to 1 . However, when the internal heat gain is as small as $59 \mathrm{~W}$, the surface temperature change due to the radiation component is within a maximum of 0.5 . When the radiative component of the internal heat gain is between 0.6 and 0.7 , it shows a constant surface temperature, regardless of the internal heat gain. 
Table 13. Cases for amount of internal heat gain.

\begin{tabular}{|c|c|c|c|c|c|c|c|c|}
\hline \multirow[b]{2}{*}{ Cases } & \multicolumn{2}{|c|}{ Group 1} & \multicolumn{4}{|c|}{ Group 2} & \multicolumn{2}{|c|}{ Group 3} \\
\hline & $\begin{array}{c}\text { Sol-Air Temp. } \\
\left({ }^{\circ} \mathrm{C}\right)\end{array}$ & $\begin{array}{c}\text { Number of Faces } \\
\text { Exposed to } \\
\text { Outdoor Air } \\
(-)\end{array}$ & $\begin{array}{c}\text { Material and } \\
\text { Composition } \\
(-)\end{array}$ & $\begin{array}{c}\text { Thickness } \\
\text { (m) }\end{array}$ & $\begin{array}{c}\text { Heat } \\
\text { Transmission } \\
\text { Coefficient } \\
\left(\mathrm{W} / \mathrm{m}^{2} \mathrm{~K}\right)\end{array}$ & $\begin{array}{c}\text { Surface Heat } \\
\text { Absorption } \\
\text { Rate } \\
(-)\end{array}$ & $\begin{array}{c}\text { Radiant } \\
\text { Fraction } \\
(-)\end{array}$ & $\begin{array}{c}\text { Heat } \\
\text { Amount } \\
\text { (W) }\end{array}$ \\
\hline \multirow{6}{*}{ IHG._59 } & \multirow{6}{*}{60} & \multirow{6}{*}{1} & \multirow{6}{*}{ Insulation 17} & \multirow{6}{*}{0.017} & \multirow{6}{*}{2.02} & \multirow{6}{*}{0.1} & 0.0 & \multirow{6}{*}{59} \\
\hline & & & & & & & 0.2 & \\
\hline & & & & & & & 0.4 & \\
\hline & & & & & & & 0.6 & \\
\hline & & & & & & & 0.8 & \\
\hline & & & & & & & 1.0 & \\
\hline \multirow{6}{*}{ IHG._0.6 } & \multirow{6}{*}{60} & \multirow{6}{*}{1} & \multirow{6}{*}{ Insulation 17} & \multirow{6}{*}{0.017} & \multirow{6}{*}{2.02} & \multirow{6}{*}{0.1} & 0.0 & \multirow{6}{*}{235} \\
\hline & & & & & & & 0.2 & \\
\hline & & & & & & & 0.4 & \\
\hline & & & & & & & 0.6 & \\
\hline & & & & & & & 0.8 & \\
\hline & & & & & & & 1.0 & \\
\hline \multirow{6}{*}{ IHG._0.9 } & \multirow{6}{*}{60} & \multirow{6}{*}{1} & \multirow{6}{*}{ Insulation 17} & \multirow{6}{*}{0.017} & \multirow{6}{*}{2.02} & \multirow{6}{*}{0.1} & 0.0 & \multirow{6}{*}{411} \\
\hline & & & & & & & 0.2 & \\
\hline & & & & & & & 0.4 & \\
\hline & & & & & & & 0.6 & \\
\hline & & & & & & & 0.8 & \\
\hline & & & & & & & 1.0 & \\
\hline
\end{tabular}

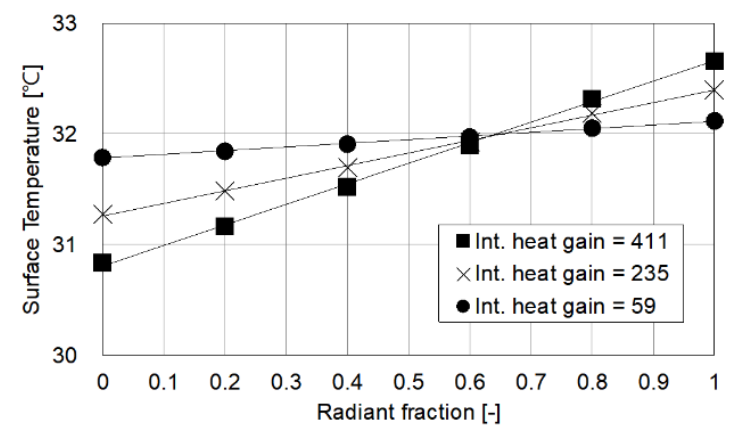

Figure 12. Radiant fraction and surface temperature for internal heat gain.

If there is no surface exposed to the outdoor environment, then the surface temperature will differ only by the effect of internal heat gain. In the case that the radiation component of internal heat gain is 1 , the surface temperature tends to increase with increasing internal heat generation. Alternatively, when the radiation component of the internal heat is less or equal to 0.6 , the amount of internal heat and the surface temperature tend to be inversely proportional to each other. The surface temperature difference according to the radiative component of the internal heat was maximum at $3.2{ }^{\circ} \mathrm{C}$ which is more than that of the outdoor exposed surface. This is because the amounts of long wave absorption and re-radiation of the surface due to the internal heat gain is increased.

- Component of internal heat gain

The surface temperature based on the change in radiation and convection component through various amounts of internal heat gain of between 59 and $411 \mathrm{~W}$ was obtained. When the radiation component of the internal heat generation was 1 , the surface temperature increased with the size of the internal heat generation. On the other hand, when the radiation component of the internal heat generation was 0 , the magnitude was inversely proportional to the surface temperature of the internal heat generation. Figure 13 presents the surface temperature derivation results based on the size of internal heat generation. 
Table 14. Cases for component of internal heat gain (exposed to outdoor air).

\begin{tabular}{|c|c|c|c|c|c|c|c|c|}
\hline \multirow[b]{2}{*}{ Cases } & \multicolumn{2}{|c|}{ Group 1} & \multicolumn{4}{|c|}{ Group 2} & \multicolumn{2}{|c|}{ Group 3} \\
\hline & $\begin{array}{c}\text { Sol-Air Temp. } \\
\left({ }^{\circ} \mathrm{C}\right)\end{array}$ & $\begin{array}{c}\text { Number of Faces } \\
\text { Exposed to } \\
\text { Outdoor Air } \\
(-)\end{array}$ & $\begin{array}{c}\text { Material and } \\
\text { Composition } \\
(-)\end{array}$ & $\begin{array}{c}\text { Thickness } \\
\text { (m) }\end{array}$ & $\begin{array}{c}\text { Heat } \\
\text { Transmission } \\
\text { Coefficient } \\
\left(\mathrm{W} / \mathrm{m}^{2} \mathrm{~K}\right)\end{array}$ & $\begin{array}{c}\text { Surface Heat } \\
\text { Absorption } \\
\text { Rate } \\
(-)\end{array}$ & $\begin{array}{c}\text { Radiant } \\
\text { Fraction } \\
(-)\end{array}$ & $\begin{array}{c}\text { Heat } \\
\text { Amount } \\
\text { (W) }\end{array}$ \\
\hline \multirow{3}{*}{ Rad._0.0 } & \multirow{3}{*}{60} & \multirow{3}{*}{1} & \multirow{3}{*}{ Insulation 17} & \multirow{3}{*}{0.017} & \multirow{3}{*}{2.02} & \multirow{3}{*}{0.1} & \multirow{3}{*}{0.0} & 411 \\
\hline & & & & & & & & 235 \\
\hline & & & & & & & & 59 \\
\hline \multirow{3}{*}{ Rad._0.2 } & \multirow{3}{*}{60} & \multirow{3}{*}{1} & \multirow{3}{*}{ Insulation 17} & \multirow{3}{*}{0.017} & \multirow{3}{*}{2.02} & \multirow{3}{*}{0.1} & \multirow{3}{*}{0.2} & 411 \\
\hline & & & & & & & & 235 \\
\hline & & & & & & & & 59 \\
\hline \multirow{3}{*}{ Rad._0.4 } & \multirow{3}{*}{60} & \multirow{3}{*}{1} & \multirow{3}{*}{ Insulation 17} & \multirow{3}{*}{0.017} & \multirow{3}{*}{2.02} & \multirow{3}{*}{0.1} & \multirow{3}{*}{0.4} & 411 \\
\hline & & & & & & & & 235 \\
\hline & & & & & & & & 59 \\
\hline \multirow{3}{*}{ Rad._0.6 } & \multirow{3}{*}{60} & \multirow{3}{*}{1} & \multirow{3}{*}{ Insulation 17} & \multirow{3}{*}{0.017} & \multirow{3}{*}{2.02} & \multirow{3}{*}{0.1} & & 411 \\
\hline & & & & & & & 0.6 & 235 \\
\hline & & & & & & & & 59 \\
\hline & & & & & & & & 411 \\
\hline Rad._0.8 & 60 & 1 & Insulation 17 & 0.017 & 2.02 & 0.1 & 0.8 & 235 \\
\hline & & & & & & & & 59 \\
\hline & & & & & & & & 411 \\
\hline Rad._1.0 & 60 & 1 & Insulation 17 & 0.017 & 2.02 & 0.1 & 1.0 & 235 \\
\hline & & & & & & & & 59 \\
\hline
\end{tabular}

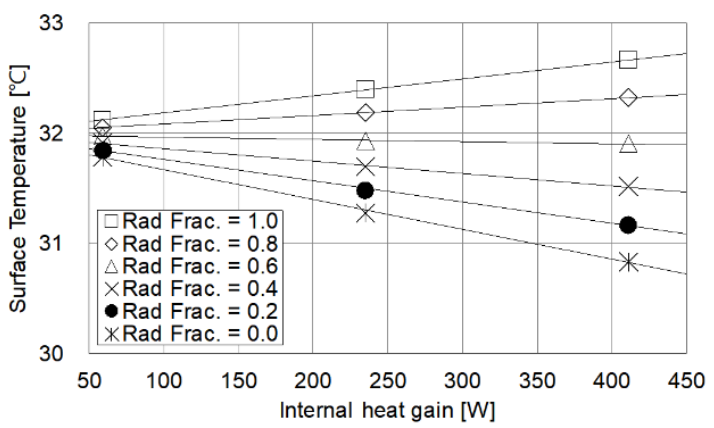

Figure 13. Internal heat gain and surface temperature for radiant fraction (exposed to outdoor air).

In this case, since the change in surface temperature due to significant outdoor temperature can be excluded, it is possible to more accurately determine whether the change in the surface temperature estimated above is as a result of internal heat generation. In the case where there is no surface exposed to the outside environment, the amount of the internal heating increases, as shown in Figure 14. This tendency was least when the radiative component of the internal heat gain was 0.8 . 
Table 15. Cases for component of internal heat gain (unexposed to outdoor air).

\begin{tabular}{|c|c|c|c|c|c|c|c|c|}
\hline \multirow[b]{2}{*}{ Cases } & \multicolumn{2}{|c|}{ Group 1} & \multicolumn{4}{|c|}{ Group 2} & \multicolumn{2}{|c|}{ Group 3} \\
\hline & $\begin{array}{c}\text { Sol-air Temp. } \\
\left({ }^{\circ} \mathrm{C}\right)\end{array}$ & $\begin{array}{c}\text { Number of Faces } \\
\text { Exposed to } \\
\text { Outdoor Air } \\
(-)\end{array}$ & $\begin{array}{c}\text { Material and } \\
\text { Composition } \\
(-)\end{array}$ & $\begin{array}{c}\text { Thickness } \\
\text { (m) }\end{array}$ & $\begin{array}{c}\text { Heat } \\
\text { Transmission } \\
\text { Coefficient } \\
\left(\mathrm{W} / \mathrm{m}^{2} \mathrm{~K}\right)\end{array}$ & $\begin{array}{c}\text { Surface Heat } \\
\text { Absorption } \\
\text { Rate } \\
(-)\end{array}$ & $\begin{array}{c}\text { Radiant } \\
\text { Fraction } \\
(-)\end{array}$ & $\begin{array}{c}\text { Heat } \\
\text { Amount } \\
\text { (W) }\end{array}$ \\
\hline \multirow{3}{*}{ Rad._0.0 } & \multirow{3}{*}{-} & \multirow{3}{*}{0} & \multirow{3}{*}{ Insulation 17} & \multirow{3}{*}{0.017} & \multirow{3}{*}{2.02} & \multirow{3}{*}{0.1} & \multirow{3}{*}{0.0} & 411 \\
\hline & & & & & & & & 235 \\
\hline & & & & & & & & 59 \\
\hline \multirow{3}{*}{ Rad._0.2 } & \multirow{3}{*}{-} & \multirow{3}{*}{0} & \multirow{3}{*}{ Insulation 17} & \multirow{3}{*}{0.017} & \multirow{3}{*}{2.02} & \multirow{3}{*}{0.1} & \multirow{3}{*}{0.2} & 411 \\
\hline & & & & & & & & 235 \\
\hline & & & & & & & & 59 \\
\hline \multirow{3}{*}{ Rad._0.4 } & \multirow{3}{*}{-} & \multirow{3}{*}{0} & \multirow{3}{*}{ Insulation 17} & \multirow{3}{*}{0.017} & \multirow{3}{*}{2.02} & \multirow{3}{*}{0.1} & \multirow{3}{*}{0.4} & 411 \\
\hline & & & & & & & & 235 \\
\hline & & & & & & & & 59 \\
\hline \multirow{3}{*}{ Rad._0.6 } & \multirow{3}{*}{-} & \multirow{3}{*}{0} & \multirow{3}{*}{ Insulation 17} & \multirow{3}{*}{0.017} & \multirow{3}{*}{2.02} & \multirow{3}{*}{0.1} & & 411 \\
\hline & & & & & & & 0.6 & 235 \\
\hline & & & & & & & & 59 \\
\hline & & & & & & & & 411 \\
\hline Rad._0.8 & - & 0 & Insulation 17 & 0.017 & 2.02 & 0.1 & 0.8 & 235 \\
\hline & & & & & & & & 59 \\
\hline & & & & & & & & 411 \\
\hline Rad._1.0 & - & 0 & Insulation 17 & 0.017 & 2.02 & 0.1 & 1.0 & 235 \\
\hline & & & & & & & & 59 \\
\hline
\end{tabular}

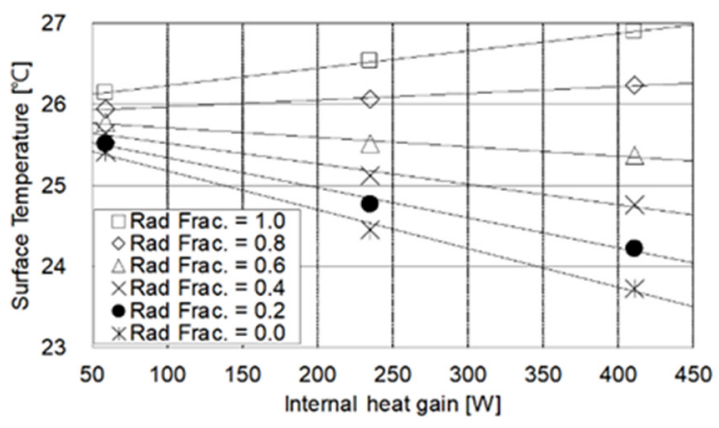

Figure 14. Internal heat gain and surface temperature for radiant fraction (unexposed to outdoor air).

\subsection{Impact Analysis of Factors}

When evaluating the cooling capacity, the boundary conditions have different values and ranges for each influencing factor. Therefore, the impact of influencing factors on the boundary condition should be simulated. The effect of the boundary condition influencing factors on the indoor surface temperature is derived when the scale of the factors is equally set. Figure 15 shows that the values of influence factors belonging to Groups 1-3 are normalized from 0 to 1 . When the value of each influence factor changes from 0 to 1 , the change in surface temperature is also normalized from 0 to 1 . 


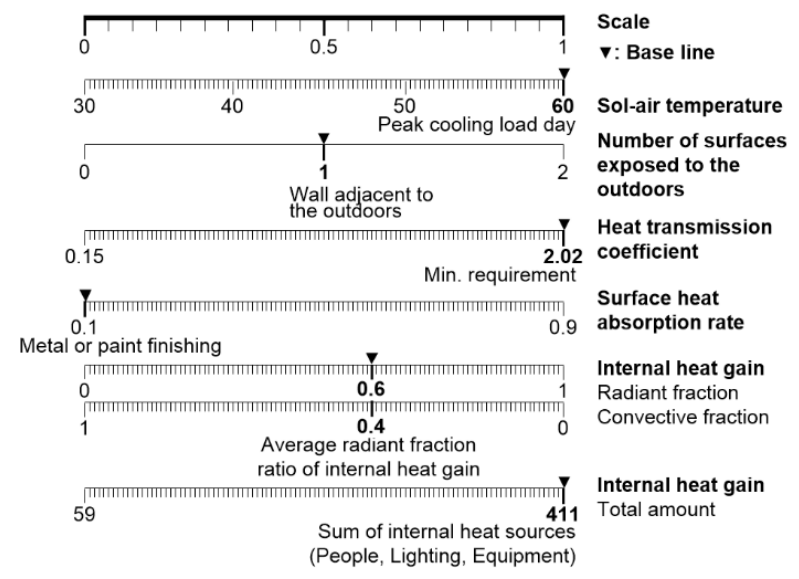

Figure 15. Scale of influencing factors.

Figure 16 shows that the factors that have the greatest influence on the boundary condition of the CRCP installed space is the number of the surfaces exposed to the outdoor environment. When the number of surfaces exposed to the outside air rises from 0 to 2 , there is significant increase in the surface temperature. Thus, the factor 'number of surfaces exposed to the outdoors' is assigned (1.0) as the reference of impact. Subsequently, the influences are significant in the following order: 'sol-air temperature' (impact 0.91), 'heat transmission coefficient' (impact 0.85), 'surface heat absorption rate' (impact 0.63), and 'component of internal heat gain' (impact 0.28). Since the influence of the surface temperature on the factors related to the site and building belonging to Group 1 is high, when evaluating the cooling capacity of the $\mathrm{CRCP}$, the surface temperature should be set based on the adjacent space and the outside air temperature. The influencing factors, which are in Group 2, are less influential compared to Group 1. The internal heat gain factors of Group 3 have relatively little effects on the surface temperature. In a room with more than one surface exposed to the outside air, the thermal load caused by the external load is dominant, compared to the other factors.

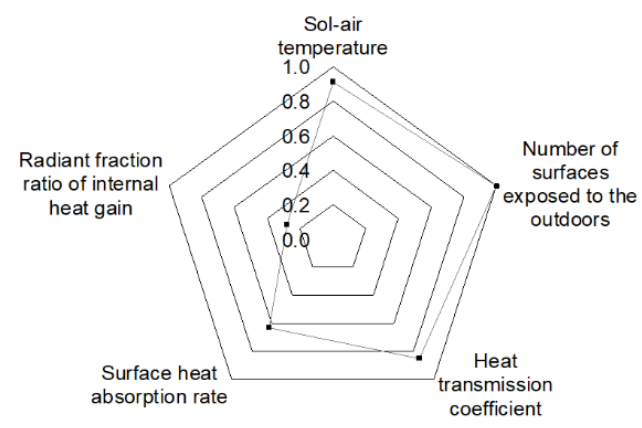

Figure 16. Impact of factors on boundary condition.

\section{Cooling Capacity According to Boundary Condition}

\subsection{Evaluation of Cooling Capacity According to Boundary Condition}

In order to verify the boundary condition and the influences of the cooling capacity evaluation derived from this study, the cooling capacity of the panel was estimated using various boundary conditions. The simulation of the cooling capacity evaluation is based on the boundary condition of the panel modeled using the EnergyPlus simulation highlighted in Section 4.1. For the calculation of the cooling capacity, the evaluation case consisted of at least three different boundary conditions in the simulation model. The cases consist of the top two factors with the most influence. Finally, the cooling capacity of the panel could be calculated at each boundary condition. Table 16 shows the configuration of the simulation case. 
Table 16. Cooling capacity according to site and building.

\begin{tabular}{|c|c|c|c|c|c|c|c|c|c|}
\hline \multirow[b]{2}{*}{ Cases } & \multicolumn{2}{|c|}{ Group 1} & & \multicolumn{2}{|c|}{ Group 2} & \multicolumn{4}{|c|}{ Group 3} \\
\hline & $\begin{array}{c}\text { Sol-Air } \\
\text { Temp. } \\
\left({ }^{\circ} \mathrm{C}\right)\end{array}$ & $\begin{array}{l}\text { Number of } \\
\text { Faces } \\
\text { Exposed to } \\
\text { Outdoor Air } \\
(-)\end{array}$ & $\begin{array}{c}\text { Material and } \\
\text { Composition } \\
(-) \\
\end{array}$ & $\begin{array}{c}\text { Thick-ness } \\
\text { (m) }\end{array}$ & $\begin{array}{c}\text { Heat } \\
\text { Transmission } \\
\text { Coefficient } \\
\left(\mathrm{W} / \mathrm{m}^{2} \mathrm{~K}\right)\end{array}$ & $\begin{array}{l}\text { Surface Heat } \\
\text { Absorption } \\
\text { Rate } \\
(-)\end{array}$ & $\begin{array}{l}\text { Radi-ant } \\
\text { Frac-tion } \\
(-)\end{array}$ & $\begin{array}{c}\text { Heat } \\
\text { Amount } \\
\text { (W) }\end{array}$ & $\begin{array}{c}\text { Nominal } \\
\text { Cooling } \\
\text { Capacity } \\
\left(\mathrm{W} / \mathrm{m}^{2}\right)\end{array}$ \\
\hline \multirow{3}{*}{ Adj._0 } & \multirow{3}{*}{60} & \multirow{3}{*}{0} & \multirow{3}{*}{ Insulation 17} & \multirow{3}{*}{0.017} & \multirow{3}{*}{2.02} & \multirow{3}{*}{0.1} & \multirow{3}{*}{0.6} & 411 & \multirow{3}{*}{76.77} \\
\hline & & & & & & & & 235 & \\
\hline & & & & & & & & 59 & \\
\hline \multirow{3}{*}{ Adj._1 } & \multirow{3}{*}{60} & \multirow{3}{*}{1} & \multirow{3}{*}{ Insulation 17} & \multirow{3}{*}{0.017} & \multirow{3}{*}{2.02} & \multirow{3}{*}{0.1} & \multirow{3}{*}{0.6} & 411 & \multirow{3}{*}{90.12} \\
\hline & & & & & & & & 235 & \\
\hline & & & & & & & & 59 & \\
\hline \multirow{3}{*}{ Adj.2 } & \multirow{3}{*}{60} & \multirow{3}{*}{2} & \multirow{3}{*}{ Insulation 17} & \multirow{3}{*}{0.017} & \multirow{3}{*}{2.02} & \multirow{3}{*}{0.1} & \multirow{3}{*}{0.6} & 411 & \multirow{3}{*}{95.32} \\
\hline & & & & & & & & 235 & \\
\hline & & & & & & & & 59 & \\
\hline \multirow{3}{*}{ Sol_60 } & \multirow{3}{*}{60} & & & & & & & 411 & \\
\hline & & 1 & Insulation 17 & 0.017 & 2.02 & 0.1 & 0.6 & 235 & 90.12 \\
\hline & & & & & & & & 59 & \\
\hline & & & & & & & & 411 & \\
\hline Sol_50 & 50 & 1 & Insulation 17 & 0.017 & 2.02 & 0.1 & 0.6 & 235 & 87.60 \\
\hline & & & & & & & & 59 & \\
\hline & & & & & & & & 411 & \\
\hline Sol_40 & 40 & 1 & Insulation 17 & 0.017 & 2.02 & 0.1 & 0.6 & 235 & 83.95 \\
\hline & & & & & & & & 59 & \\
\hline & & & & & & & & 411 & \\
\hline Sol_30 & 30 & 1 & Insulation 17 & 0.017 & 2.02 & 0.1 & 0.6 & 235 & 79.37 \\
\hline & & & & & & & & 59 & \\
\hline
\end{tabular}

\subsection{Evaluation Results of Cooling Capacity}

When the sol-air temperature increases from 30 to $60{ }^{\circ} \mathrm{C}$ the nominal cooling capacity of the panel increases from $10.75 \mathrm{~W} / \mathrm{m}^{2}$ to between 79.37 and $90.12 \mathrm{~W} / \mathrm{m}^{2}$ (Figure 17). This tendency is more pronounced when the sol-air temperature is higher. When the number of exposed surfaces increases from 0 to 2, the nominal cooling capacity of the panel increases from 76.77 to $95.32 \mathrm{~W} / \mathrm{m}^{2}$. As a result, the nominal cooling capacity of the panel is highly evaluated with the same CRCPs (Figure 18). When the number of exposed surfaces is three or more, the supply water temperature of the CRCP becomes excessively low, and the supply water-return temperature difference becomes larger than the design standard. In this case, it is impossible to eliminate all the thermal loads generated in the room by the panel only, and a secondary system is required.

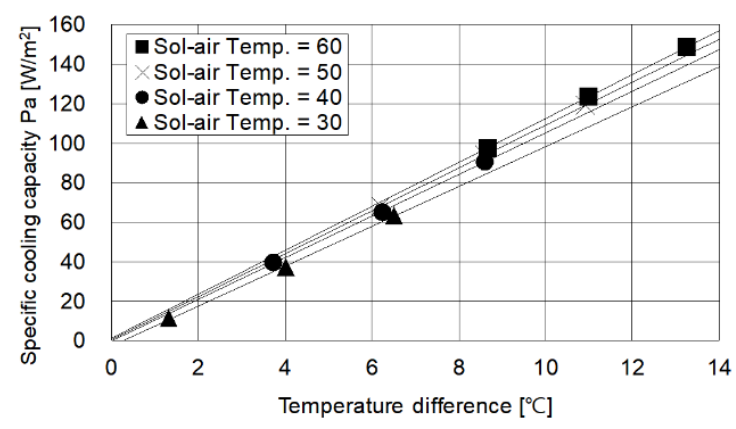

Figure 17. Cooling capacity according to sol-air temperature. 


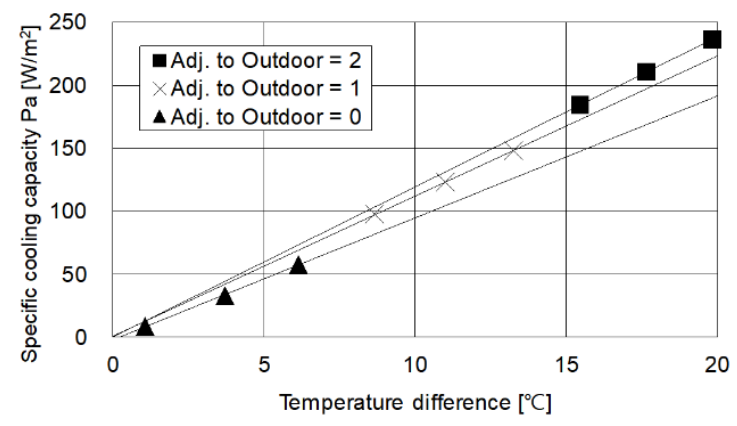

Figure 18. Cooling capacity according to adjacent to outdoor air.

\subsection{Verification Experiment of Boundary Condition Derivation Model}

In order to verify the simulation, the boundary condition for cooling capacity analysis was experimentally implemented using the same method, and the results were compared with the simulation results (Figure 19) [20-23]. Table 17 shows that the verified boundary conditions in the experiment includes the flow rate, supply water temperature, the wall surface temperature, and the internal heat gain $[24,25]$.

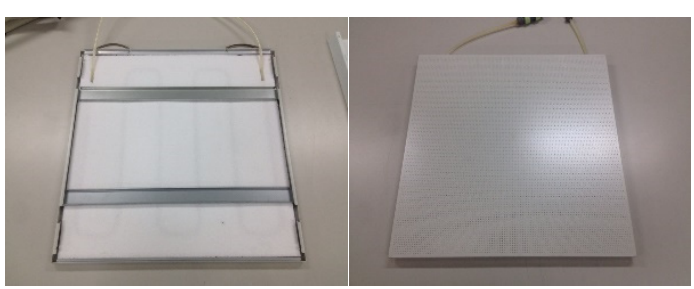

(a)

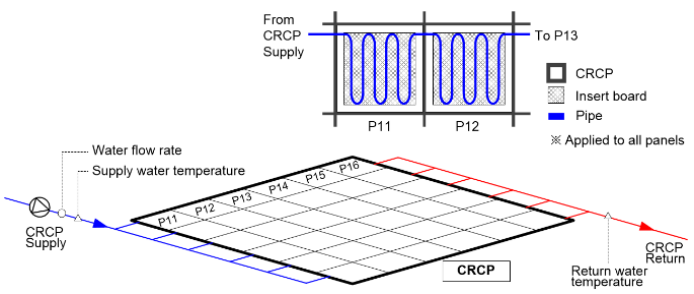

(c)

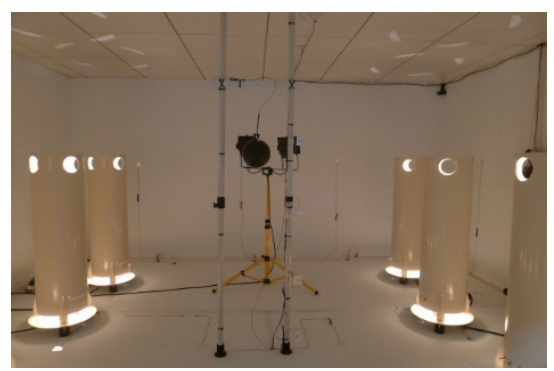

(e)

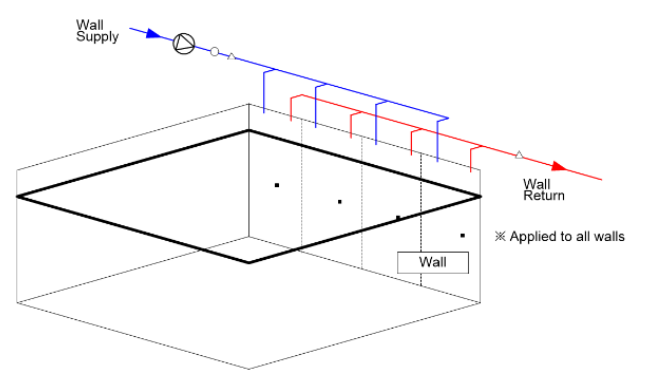

(b)

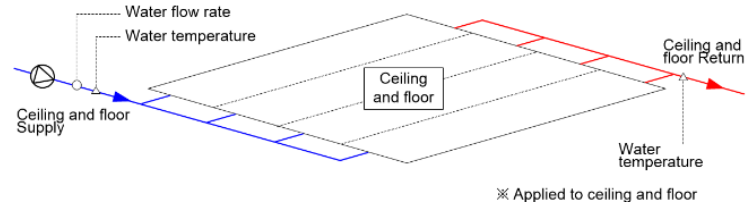

(d)

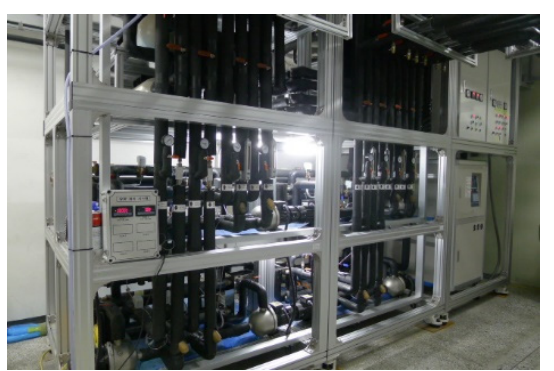

(f)

Figure 19. Experimental evaluation of the cooling capacity of the CRCP: (a) Cooling Radiant Ceiling Panel; (b) test cell wall distribution system; (c) CRCP joint and distribution system; (d) ceiling and floor distribution system; (e) indoor of test cell with wall temperature control; (f) heat source for CRCP and walls. 
Table 17. Boundary condition for cooling capacity evaluation experiments.

\begin{tabular}{|c|c|c|c|c|c|}
\hline \multicolumn{3}{|c|}{ Cases } & Cooling 1 & Cooling 2 & Cooling 3 \\
\hline \multicolumn{2}{|c|}{ Boundary condition } & Unit & & Results & \\
\hline \multicolumn{2}{|c|}{ Water flow rate } & $(\mathrm{kg} / \mathrm{s})$ & 0.153 & 0.153 & 0.153 \\
\hline \multirow{10}{*}{ Temperature } & Inlet water & $\left({ }^{\circ} \mathrm{C}\right)$ & 11.4 & 14.0 & 16.7 \\
\hline & Outlet water & $\left({ }^{\circ} \mathrm{C}\right)$ & 14.9 & 17.0 & 19.0 \\
\hline & Globe air (height $1.1 \mathrm{~m}$ ) & $\left({ }^{\circ} \mathrm{C}\right)$ & 27.0 & 26.8 & 26.5 \\
\hline & Front wall surface & $\left({ }^{\circ} \mathrm{C}\right)$ & 32.5 & 32.6 & 32.6 \\
\hline & Back wall surface & $\left({ }^{\circ} \mathrm{C}\right)$ & 25.4 & 25.4 & 25.5 \\
\hline & Left wall surface & $\left({ }^{\circ} \mathrm{C}\right)$ & 25.4 & 25.4 & 25.5 \\
\hline & Right wall surface & $\left({ }^{\circ} \mathrm{C}\right)$ & 25.4 & 25.4 & 25.5 \\
\hline & Floor & $\left({ }^{\circ} \mathrm{C}\right)$ & 25.0 & 25.9 & 26.0 \\
\hline & Ceiling & $\left({ }^{\circ} \mathrm{C}\right)$ & 24.0 & 25.5 & 26.0 \\
\hline & Plenum air & $\left({ }^{\circ} \mathrm{C}\right)$ & 24.9 & 25.0 & 25.0 \\
\hline \multicolumn{2}{|c|}{ Internal heat gain } & $(W)$ & 411 & 235 & 59 \\
\hline \multirow{2}{*}{ Temperature } & Temp. rise & $\left({ }^{\circ} \mathrm{C}\right)$ & 3.56 & 2.96 & 2.34 \\
\hline & Temp. difference & $\left({ }^{\circ} \mathrm{C}\right)$ & 13.85 & 11.30 & 8.66 \\
\hline \multirow{2}{*}{$\begin{array}{l}\text { Cooling } \\
\text { capacity }\end{array}$} & Nominal & $\left(\mathrm{W} / \mathrm{m}^{2}\right)$ & 153.02 & 127.23 & 100.13 \\
\hline & Total amount & $(W)$ & 1088 & 905 & 712 \\
\hline
\end{tabular}

Figure 20 shows that the cooling capacity of the CRCP is $100.1-153.0 \mathrm{~W} / \mathrm{m}^{2}$ at a constant flow rate of $0.153 \mathrm{~kg} / \mathrm{s}$ and a supply water temperature of $11-17^{\circ} \mathrm{C}$ Table 18 shows that the nominal cooling capacity of CRCP is $93.2 \mathrm{~W} / \mathrm{m}^{2}$. As a result of the experiment, the difference in cooling amount from the simulation model is approximately $3.08 \mathrm{~W} / \mathrm{m}^{2}$. In the simulation, the cooling capacity of the CRCP may vary based on the modeling technique, in addition to the detail of adhesion between various members and joints constituting the panel [26]. The cooling capacity estimated in the simulation and experiment has an agreement of $96.7 \%$. As a result of the experiment, the validity of the simulation model was verified.

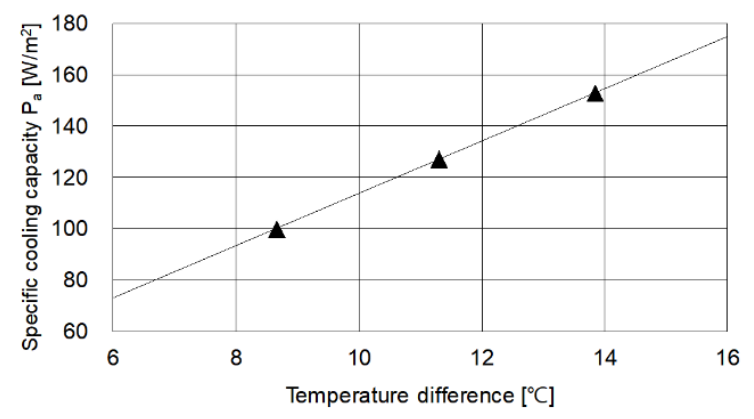

Figure 20. Test result for the cooling capacity of the CRCP.

Table 18. Nominal cooling capacity of CRCP.

\begin{tabular}{cccc}
\hline Panel Name & $\begin{array}{c}\text { Nominal Cooling Capacity } \\
\left(\mathbf{W} / \mathbf{m}^{2}\right)\end{array}$ & $\begin{array}{c}\text { Characteristic Coefficient k } \\
(-)\end{array}$ & $\begin{array}{c}\text { Exponential Coefficient } \mathbf{~} \\
(-)\end{array}$ \\
\hline CRCP & 93.20 & 14.253 & 0.903 \\
\hline
\end{tabular}




\section{Conclusions}

In this study, the boundary condition for the evacuation of cooling capacity of the CRCP according to various boundary condition influencing factors was derived. According to the results of this study, it can be seen that the cooling capacity of the CRCP varies depending on the boundary conditions. In particular, when the space in which the CRCP is installed is exposed to a large area of outside air, and when the outdoor temperature is high, the nominal cooling capacity of the panel could be overestimated. The reason is that excessive radiation and convective heat transfer between the test room and the CRCP may occur. Particular attention should be paid to the calculation of the cooling capacity, especially when installing the ceiling radiant cooling panels adjacent to the walls exposed to the outside air. In addition, the same results are obtained even when the surface heat absorption rate and thermal conductivity of the wall are high. The results of this study, in which the cooling capacity of the CRCPs can be estimated in various boundary conditions, are expected to be a significant design basis for applying the panels. In the future, the airflow analysis of the space with CRCPs using CFD will be carried out according to the boundary conditions derived from this study [27].

Author Contributions: Conceptualization, S.-R.R. and M.-S.Y.; Data curation, G.-S.J.; Investigation, S.-H.P. and S.-R.R.; Methodology, S.-H.P.; Project administration, K.-W.K.; Software, S.-H.P. and D.-W.K.; Supervision, M.-S.Y. and K.-W.K.; Validation, S.-H.P. and G.-S.J.; Visualization, D.-W.K.; Writing-original draft, S.-H.P.; Writing-review and editing, S.-R.R. All authors have read and agreed to the published version of the manuscript.

Funding: This research was funded by the Korea Institute of Energy Technology Evaluation and Planning (KETEP) and the Ministry of Trade, Industry and Energy (MOTIE) of the Republic of Korea, grant number 20189220100060. The APC was funded by 20189220100060.

Acknowledgments: This work was supported by the Korea Institute of Energy Technology Evaluation and Planning (KETEP) and the Ministry of Trade, Industry and Energy (MOTIE) of the Republic of Korea.

Conflicts of Interest: The authors declare no conflict of interest.

\section{References}

1. Imanari, T.; Omori, T.; Bogaki, K. Thermal comfort and energy consumption of the radiant ceiling panel system. Comparison with the conventional all-air system. Energy Build. 1999, 30, 167-175. [CrossRef]

2. Antonopoulos, K.A.; Vrachopoulos, M.; Tzivanidis, C. Experimental evaluation of energy savings in air-conditioning using metal ceiling panels. Appl. Therm. Eng. 1998, 18, 1129-1138. [CrossRef]

3. Fonseca, N. Experimental study of thermal condition in a room with hydronic cooling radiant surfaces. Int. J. Refrig. 2011, 34, 686-695. [CrossRef]

4. ANSI/ASHRAE. Standard 138-2009, Method of Testing for Rating Ceiling Panels for Sensible Heating and Cooling; American National Standards Institute/American Society of Heating, Refrigerating and Air-Conditioning Engineers: Atlanta, GA, USA, 2009.

5. Comité Européen de Normalisation (CEN). Water Based Surface Embedded Heating and Cooling Systems-Part 2: Floor Heating: Prove Methods for the Determination of the Thermal Output Using Calculation and Test Methods; Standard EN 1264-2; Comité Européen de Normalisation: Brussels, Belgium, 2012.

6. Babiak, J.; Olesen, B.W.; Petras, D. Low Temperature Heating and High Temperature Cooling: REHVA Guidebook No. 7; Federation of European Heating, Ventilation and Air Conditioning Associations: Brussels, Belgium, 2007.

7. ASHRAE. 2016 ASHRAE Handbook -HVAC Systems and Equipment, Ch.6 Radiant Heating and Cooling; American Society of Heating, Refrigerating and Air-Conditioning Engineers: Atlanta, GA, USA, 2016.

8. LBNL. Development of a Simulation Tool to Evaluate the Performance of Radiant Cooling Ceilings; CIEE Report; LBNL: Berkeley, CA, USA, 1995; p. 138.

9. Kochendorfer, C. Standardized testing of cooling panels and their use in system planning. Ashrae Trans. Symp. 1996, 102, 651-658.

10. Fonseca, N.; Cuevas, C.; Lemort, V. Radiant ceiling systems coupled to its environment part 1: Experimental analysis. Appl. Therm. Eng. 2010, 30, 2187-2195. [CrossRef]

11. De Carli, M.; Scarpa, M.; Tomasi, R.; Zarrella, A. A numerical model for the thermal balance of rooms equipped with radiant systems. Build. Environ. 2012, 57, 126-144. [CrossRef] 
12. Tian, Z.; Yin, X.; Ding, Y.; Zhang, C. Research on the actual cooling performance of ceiling radiant panel. Energy Build. 2012, 47, 636-642. [CrossRef]

13. Comité Européen de Normalisation (CEN). Ventilation for Buildings-Chilled Ceilings-Testing and Rating Offers a Testing Method for Chilled Ceilings; British Standard EN14240:2004; Comité Européen de Normalisation: Brussels, Belgium, 2004.

14. Nordic. Ceiling Cooling Systems: Cooling Capacity (NT VVS 078); Nordic: Oslo, Norway, 2001.

15. ASHRAE. 2013 Handbook -Fundamentals, Ch. 18 Nonresidential Cooling and Heating Load Calculations; American Society of Heating, Refrigerating and Air-Conditioning Engineers: Atlanta, GA, USA, 2013.

16. Mills, A.F. Basic Heat E Mass Transfer; Prentice Hall: Saddle River, NJ, USA, 1999.

17. Chantrasrisalai, C.; Fisher, D.E. Lighting Heat Gain Distribution in Buildings (RP-1282); ASHRAE Research Project, Final Report; ASHRAE: Atlanta, GA, USA, 2006.

18. Winkins, C.; Hosni, M.H. Heat gain from office equipment. Ashrae J. 2000, 42, 33-44.

19. LBNL. ENERGYPLUS Input Output Reference. LBNL 2013, 11, 1-3.

20. Ryu, S.R.; Rhee, K.N.; Yeo, M.S.; Kim, K.W. Strategies for flow rate balancing in radiant floor heating systems. Build. Res. Inf. 2008, 36, 625-637. [CrossRef]

21. Jeong, J.W.; Mumma, S.A. Ceiling radiant cooling panel capacity enhanced by mixed convection in mechanically ventilated spaces. Appl. Therm. Eng. 2003, 23, 2293-2306. [CrossRef]

22. Jeong, J.W.; Mumma, S.A. Simplified cooling capacity estimation model for top insulated metal ceiling radiant cooling panels. Appl. Therm. Eng. 2004, 24, 2055-2072. [CrossRef]

23. Park, S.H.; Kim, D.W.; Yeo, M.S.; Kim, K.W. An Experiment for Estimating the Cooling Capacity of the Radiant Ceiling Panel System. J. Archit. Inst. Korea Plan. Des. 2014, 30, 267-276. [CrossRef]

24. Kim, T.Y.; Kato, S.; Murakami, S.; Rho, J.W. Study on indoor thermal environmental of office space controlled by cooling panel system using field measurement and the numerical simulation. Build. Environ. 2005, 40, 301-310. [CrossRef]

25. Lim, J.H.; Jo, J.H.; Kim, Y.Y.; Yeo, M.S.; Kim, K.W. Application of the control methods for radiant floor cooling system in residential buildings. Build. Environ. 2006, 41, 60-73. [CrossRef]

26. Miriel, J.; Serres, L.; Trombe, A. Radiant ceiling panel heating-cooling systems: Experimental and simulated study of the performances, thermal comfort and energy consumptions. Appl. Therm. Eng. 2002, 22, 1861-1873. [CrossRef]

27. Shin, M.S.; Rhee, K.N.; Park, S.H.; Yeo, M.S.; Kim, K.W. Enhancement of cooling capacity through open-type installation of cooling radiant ceiling panel systems. Build. Environ. 2019, 148, 417-432. [CrossRef] 